\title{
SAFETY AND SECURITY STUDIES OF RAILWAY LINES WITH PUBLIC ROADS (CASE STUDY OF RAILROAD CROSSING IN THE KENJERAN ROAD OF SURABAYA CITY)
}

\author{
Irwan Mahmudi, \\ Faculty of Engineering, Narotama University Surabaya \\ Irwanmahmudi32@gmail.com \\ Sri Wiwoho Mudjanarko \\ Faculty of Engineering, Narotama University Surabaya \\ sri.wiwoho@narotama.ac.id
}

\begin{abstract}
Railways are a mode of transportation that is being liked by the public because of its efficiency. The train has its own road in the form of rails, it doesn't mean the train doesn't intersect other transportation. The train crossing is a conflict area for public road users with train. This includes train crossing at Kenjeran street. The kenjeran street itself is a national road that is quite strategic because it is one of the accesses to the Surabaya-Madura toll road. The research this time aims to find out the security aspects that must be improved at the train crossing kenjeran street. Including rider behaviour at the time of the train crossing. The method used for this research is direct observation of the field and also shares questionnaires to find out if a public road user understands regulations while on a train crossing. The research results of many signs or road markers are incomplete so that many road users do not know that in front of the train crossing. Other public road user behaviour is also a lot of offense.
\end{abstract}

Keywords: Train, Crossing train, safety, secur,transportation.

\section{INTRODUCTION}

Transportation in Indonesia very much and various types of private vehicles included. (Muhtadi, 2012) argues that the users of the road today are using private vehicles, either using two-wheeled vehicles or four wheels. Because of the many private vehicles.(Limantara, A. D., Candra, A. I., \& Mudjanarko, 2017) argues that will cause a large impact in the form of congestion, theft of private vehicles that continue to increase, to damage the pavement.

Therefore the train emerged as a solution to congestion that occurred in many major cities in Indonesia. As the operator of the Indonesian railways PT. KAI also continues to make trains as the best mode of transportation through many of the latest series of train carriages for passenger comfort.

Rail access for railways has also been widely connected in big cities and trains prioritize their trips compared to other public road users causing many problems. Among them are accidents that occur at the intersection of a train and public road users. According to the report (Komisi Nasional Keselamatan Transportasi, 2016) In 2010-2016 there were 35 incidents involving railways and $6 \%$ caused by trains and other ground transportation and pedestrian modes. So from that the purpose of this study is to find out how the behavior of road users when on the train crossing. 
The cause of accidents involving trains can also occur because the signposts are not properly installed. This research also uses methods by ventarizing things in the field. So it can be explained clearly whether the signs and fittings on the crossing also affects in the event of a railway crossing incident. Hopefully this research is also expected that the public can realize that the importance of safety and security when driving while at a train crossing.

Research purposes

1. To find out whether a field crossing by train is already in compliance with technical standards.

2. To find out the feasibility of signs and guards at railroad crossings and public roads.

3. To find out what is the visibility for drivers and also public road users.

4. Knowing the behavior of the people who crossed the railroad crossings and know the level of safety and security of transportation at railroad crossings.

\section{METHODOLOGY}

This study used a descriptive method because this research only describes the incident when it occurs in the research process.

\section{Data Collection Techniques}

Data collection In this study there are various kinds. The following are the ways that authors use:

a. Equipment Data on the train crossing

Data collection to determine what equipment is on a crossing by performing a live observation on the field and then logged in the inventory sheet. Documentation with the camera is also required to support data collection.

b. Physical condition Data on train crossing

Retrieval of data on the physical condition of crossings is done by measuring using a tape meter and recording the width of the highway under study, recording in the inventory sheet and also documenting with the camera.

c. Completeness on the highway

Completeness on the highway can be done by making direct observations and then recording what signs are in the field and then documented using a camera. The marker line is also measured using a tape meter to determine the distance of the markers with the train crossing doors and then recorded.

d. Data on road user behavior is taken from direct observation in the field and then documented / photographed. The questionnaire form is needed to add this data collection.

\section{Railway Crossing Equipment Kenjeran Road}

PJL 03 on the Surabaya road is a crossing that is officially guarded by officers from PT. KAI uses semi-automatic crossing doors. The crossing on this road has several equipment that are quite complete in the form of sirens and lights for reminders, crossings to warn road users will pass. Equipment is quite effective.

Officers who guarded the crossings during the observation looked very alert and very fast when they got a telephone to close the crossing door. From the results of the questionnaire asked to the public, $92 \%$ of respondents said that the crossing guard was very alert in closing the door.

The material used for crossing doors is made of wood which is very thin and very vulnerable to being broken if hit by a vehicle that breaks through the crossing. The crossing door when there is damage or a broken hit by a public road user, then the PES officer who is serving at that time must be alert to dismiss other public road users and immediately contact the nearest station to the PES. PJL 03 happens to be not far from the station even though it is on the sidotopo 
locomotive, if an accident occurs such as a broken doorstop, the officer will contact the station to send security to help regulate traffic around the crossing even if there is severe congestion. crossing. The height of the crossing door when closed was about $80 \mathrm{~cm}$ high.

In (Director General Decree 770 of 2005) there are technical regulations for level crossings, namely as follows:

1. Genta / voice signal with a power of $115 \mathrm{db}$ at a distance of 1 meter.

2. list of slogans.

3. authorized officers.

4. list of official staff.

5. guard posts and facilities

6. list of train trips according to the Railway Travel Chart (GAPEKA)

7. The motto of the flag is red and green and the motto lights.

8. Other equipment such as flashlights, first aid kits, wall clocks.

9. doors with strong and lightweight requirements, anti-rust and easy to see and meet the failsafe criteria for electric doors.

Whereas what is found at the Kenjeran road crossing is complete as in SK dirjen in 2005. The following are functions of several facilities contained in the guard post.

\section{Completeness of Signs for Kenjeran Highway}

From the data in the field, the Surabaya road crossing has many disadvantages for signs. Though signs are useful as a reminder that motorists or public road users will soon enter the railroad crossing area. As a national road, roads will require a lot of stimulus to facilitate travel and not to have accidents. For this reason, the Sub-dept. And parties from DAOP 8 Surabaya should work together to install signs as a warning. 2005).

The following are signs that need to be installed according to the rules (SK dirjen 707 at

a. Sign No. 5 in the form of words so that the driver is careful to enter the railroad track. This sign is installed 100 meters from the stop sign.

b. No. 12 warning sign stating that the driver pauses to ensure that no passing train is installed at least 30 meters from the outermost side of the rail.

c. No22 sign B which is installed 50 meters from the stop sign crossing.

While on Kenjeran street alone there are only 3 signs that are in accordance with the regulations of the SK of Decree 770 of 2005.

a. 1 . Sign No. 1 which is an appeal sign to stop which is 2.5 meters from the outermost rail side.

b. 2. Sign no. 1c and the lamp installed 4.5 meters from the side of the outer rail.

c. 3. Andrea cross signs that are installed 50 meters from the outermost rail side. As for the road markers needed by the ramp are

a. 1. Transverse markings in the form of transverse lines which means the sign must stop 4.5 meters from the side of the outermost rail

b. 2. Markers equipped with railroad writing and 50 meters long stretch of crossing markers.

c. 3. Rumble strips before entering plot crossing as a stimulus to road users that they enter the careful area and in front of something dangerous. The following is a picture of road crossings if it is in accordance with the SK Dirjen 770 Decree of 2005. 


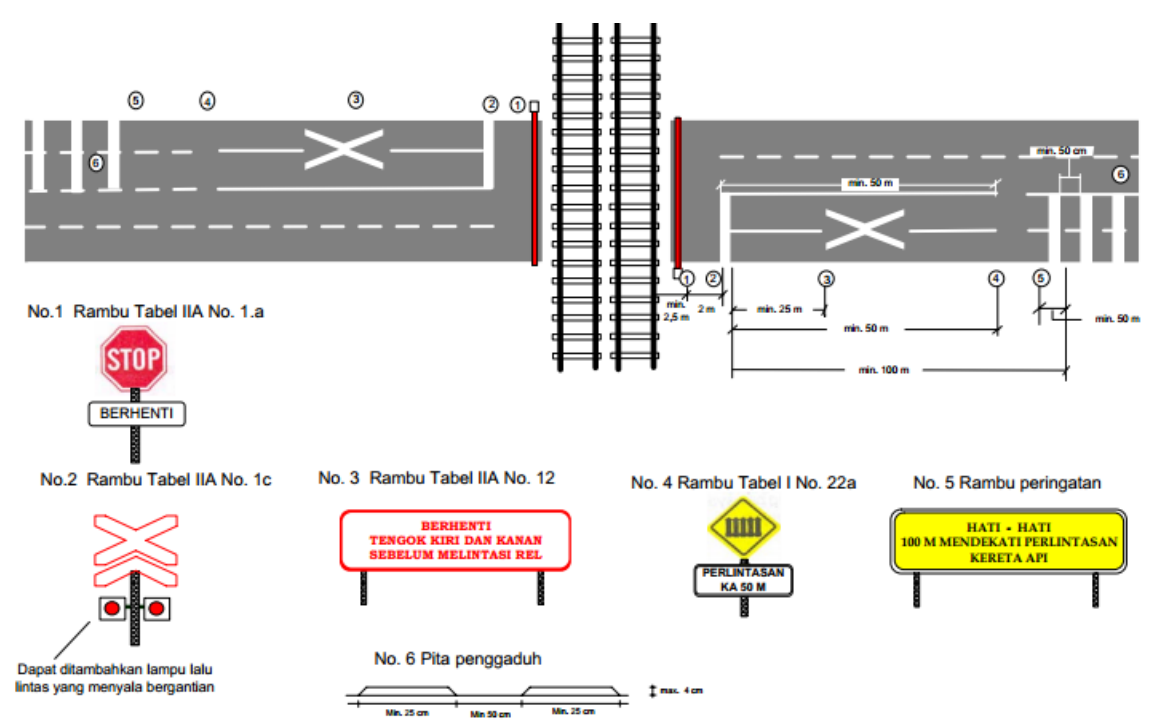

Figure 1: Crossing in accordance with decree of the directorate general of 707 in 2005

\section{Visibility}

Buildings located on the left or right of the rail can also interfere with train travel. Visibility that disrupts drivers and public road users can be fatal because the train can only stop perfectly with a meter of 500 meters after the brake lever is pulled by a machinist. therefore engineers can only rely on crossing guards to reduce accidents with public road users. Engineers can only use the slogan 35 to remind public road users around to be careful and pay attention to the presence of the train. Following is the calculation of the minimum visibility for the engineer and also the users of public roads on the Kenjeran Road Surabaya:

The following values are known:

$\mathrm{Vt}=60 \mathrm{~km} / \mathrm{h}$ (train speed is traversed)

$\mathrm{Vv}=50 \mathrm{~km} /$ hour (Speed on national roads)

$\mathrm{D}=4.5$ meters

de $=3$ meters

$\mathrm{L}=20$ meters

$\mathrm{W}=1.5$ meters

$f=-0.000165 \mathrm{Vv}+0.192$

$f=0.000165(50)+0.192$

$\mathrm{f}=0.1595$ meters

$\mathrm{t}=2.5$ meters

visibility of public road users from the railroad tracks

$\mathrm{dH}=0.28 \mathrm{Vvt}+\frac{\mathrm{Vv}^{2}}{254 \mathrm{f}}+\mathrm{D}+\mathrm{de}$

$\mathrm{dH}=0.28(50)(2.5)+\frac{50^{2}}{254(0.1595)}+4.5+3$

$\mathrm{dH}=104$ meter.

Visibility for train engineers for public road users

$\mathrm{d}_{\mathrm{T}}=\frac{V T}{V v}\left[\frac{\mathrm{Vv}}{254 \mathrm{f}}+2 \mathrm{D}+\mathrm{L}+\right.$ W] $\ldots$

$d_{T}=\frac{60}{50}\left[\frac{50^{2}}{254(0.1595)}+2(4.5)+20+1.5\right]$
$d_{T}=152$ meter. 
Actually the law has been regulated in (Minister of Transportation Decree No. KM 53 of 2000 concerning the Intersection and / or Interference between Railway and Other Buildings, 2000) article 4 paragraph 2 which reads a minimum free distance of 500 meters for train drivers and 150 meters for drivers of motorized vehicles as referred to in paragraph (1) letter $f$ intended for each to pay attention to signs or signs, and specifically for motorized vehicle drivers must stop their vehicles.

The following is a comparison of visibility in the minister's decision no 53 of 2000 with the conditions in the field.

a. The visibility of road users in the minister's decision is 150 meters while the field conditions are only 6 meters from the rail.

b. The machinist's visibility in the Minister of Finance's decision No. 53 of 2000 should be 500 meters while the field is only 7 meters.

According to the results of the above calculation, the machinist's visibility is 152 meters which means the engineer must be able to see the condition of the road at the crossing. Meanwhile, for public road users have a distance of 104 meters to find out if there is a train that will walk to the crossing. As a result of the buildings on the left and right of the railroad roads, it is not possible to have an ideal view that matches the results of the above calculation. The solution to this point of view is that drivers and road users adhere to the signs that have been installed. Demolition of buildings that interfere with visibility can be another option, because the land around the road is owned by PT. KAI does not require compensation.

\section{Public Road User Behavior}

Road users in PJL 03 on road roads at the time of observation on the field had many violations committed by the public road users themselves. Motorists are increasingly driving faster when the crossing door will be closed. Road users will slow down the vehicle if the road they pass through has a hole in the intersection with the rail.

The users of motorcycle transportation are the most violating especially when the crossing doors are closed. The average motorcycle user uses the space in front of the doorstop that has been closed to stop. even though it is very dangerous for the public road users themselves.

Crossing guards themselves often whistle or even call security to help regulate traffic jams caused by road users who do not want to fight when the crossing door will be closed.

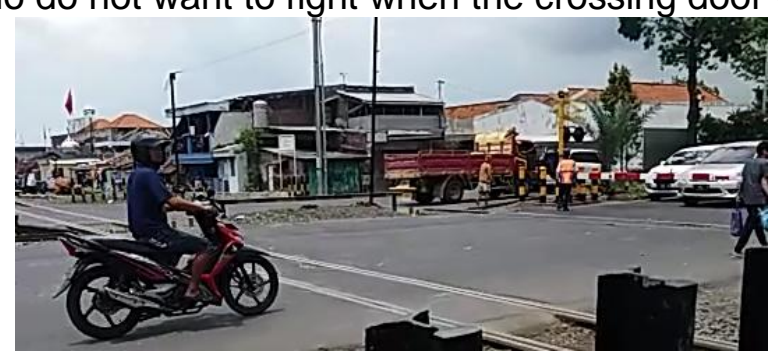

Figure 2. The PJL guard officer reprimands the truck driver for causing traffic jams.

The motorbike riders from the direction of kedung cowek who will head towards kapasan mostly turn back on the railroad, this can be dangerous because the rail surface is slippery in the event of rain. 


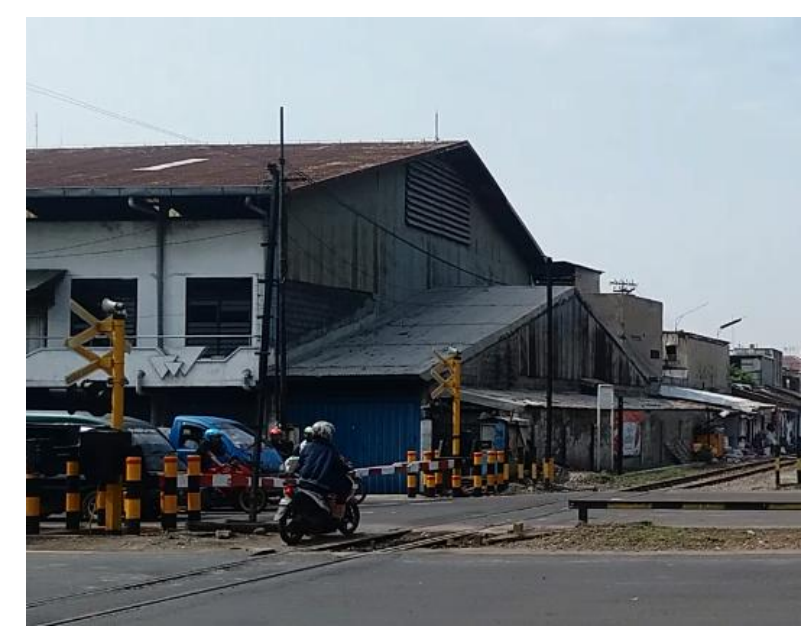

Figure 3. Road users rotating directions on the railroad tracks

PT. KAl itself has given an obstacle in the form of planting iron rails between spaces between rails and space that allows the vehicle to turn around.

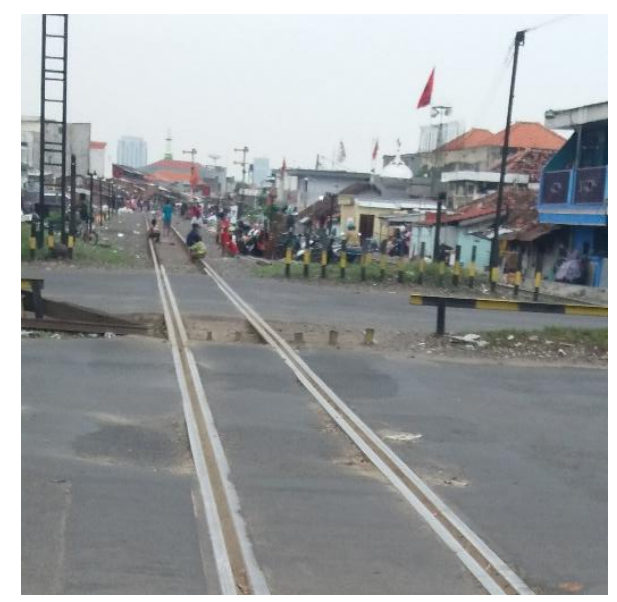

Figure 4. Planted iron to drive riders turning on the rails

The results of the questionnaire also asked. when you pass the railway crossing the kenjeran road, do you see the train crossing signs? and the answer.

- 35 people answered yes $(70 \%)$

- 15 people answered no (30\%).

But the results of the questionnaire were contrary to the results of the observation, there were signs in front of the door but many people pretended not to see and pay attention to the PES guards.

And the people who crossed the train crossing did not even know the function of the train's doorstop, the results of the questionnaire proved when asked whether the function of the railroad door.

- 47 people answered protecting road users (94\%).

- 3 people responded to protect train travel $(6 \%)$.

It has been explained in (PP No. 2009 concerning Traffic and Railway Transportation) article 110 paragraph 4 which reads as follows

The crossing door on a plot of intersection serves to secure train travel.

The solution to reduce violations of road users who turn back and forth on the rail is to use a double crossbar so that the number of door bars is before the crossing and after the crossing 
of the Train. To reduce the number of riders who break through it is better to put up banners or warning boards about penalties and fines if you break a train crossing.

\section{CONCLUSSION}

1. The crossing of the Kenjeran road or PJL 03 has met the technical requirements of a railway crossing with a door. By fulfilling the requirements contained in 2005 Director General 707 decree in the form of bell, list of slogans, guarded by authorized officers, list of officers, guard posts and facilities, list of train trips in accordance with GAPEKA, flag slogan, other equipment such as flashlights, boxes First aid kits, wall clocks, doors with strong and lightweight requirements, anti-rust and easy to see and meet the failsafe criteria for electric doors

2. Signs for security stimulus for public road users on road intersections intersecting with railroad tracks are still incomplete including road markers which have not existed at all on the Surabaya road.

3. After calculating using the formula, the minimum visibility at railroad crossings is 152 meters for machinists and 104 meters for public road users.

4. The behavior of public road users on road safety is proven to be very poor knowledge of the function of the door bar at the crossing obtained from the questionnaire questions 47 people $(94 \%)$ answered the function of the doorstop is to secure road users even though the use of the doorstop is used to secure train trip. While at the time of the field as many as 616 violations that occurred and the most violations dominated, namely continuing to run even though the warning sireine had been heard with the number 329 violations and dominated by motorcycle transportation users with 124 violators in the afternoon.

\section{REFERENCES}

Keputusan Menteri Perhubungan Nomor KM 53 Tahun 2000 Tentang Perpotongan Dan/Atau Persinggungan Antara Jalur Kereta Api Dengan Bangunan Lain. (2000).

Komisi Nasional Keselamatan Transportasi. (2016). Data Investigasi Kecelakaan Perkeretaapian Tahun 2010 - 2016 Ketua Sub Komite, 2016(November).

Limantara, A. D., Candra, A. I., \& Mudjanarko, S. W. (2017). Manajemen Data Lalu Lintas Kendaraan Berbasis Sistem Internet Cerdas Ujicoba Implementasi Di Laboratorium Universitas Kadiri. Prosiding Semnastek, (November), 1-2.

Muhtadi, A. (2012). Evaluasi Pelayanan Bus Dan Mpu Kota Surabaya, 2-7. Pp No Tahun 2009 Tentang Lalu Lintas Dan Angkutan Kereta Api. (N.D.). SK dirjen 770 Tahun 2005. 